\title{
The Contribution Of Compensation In The Employee Retention Of The Banking Institutions In Dar Es Salaam, Tanzania
}

\author{
A. E. Hanai and W. A. Pallangyo
}

\begin{abstract}
This paper explores the influence of compensation on employee retention of the banking institutions in Tanzania. The stratified sampling technique was used to ensure representativeness of each bank category. Eleven banks were purposely selected and simple random sampling was applied to draw a sample of 370 employees. The quantitative data were collected using questionnaire and analyzed using Binary logistic regression. The results indicated that compensation is significantly influencing employee retention with a ' $p$ ' value of 0.001 . It was further revealed that compensation attribute (fair salary) has significant influence on employee retention. The study recommends to the bank managers to develop and implement retention policies that contemplate fair salaries as this is a most valued compensation attribute. Furthermore, the bank managers need to pay great attention to right retention policies in order to improve retention of employees.
\end{abstract}

Index Terms - Employee retention, Compensation, Bank institutions.

\section{INTRODUCTION}

In recent years, the employee retention trends have become a serious concern to many organizations regardless of size [35]. Many scholars, including Johari et al. [22] and Manogharan et al. [35] have stressed that the success of any organization depends on the employees as they are the greatest asset. The business environment is becoming very competitive and the knowledgeable and skilled employees have become the major differentiating factor in most organizations [63]. Many organizations including the bank institutions rely on the employees' expertise to compete and gain competitive advantage. Diversely, Ibidunni et al. contended that employee retention helps in improving organizational performance and competitiveness in the businesses [20].

The existence of competition in banking institutions in Tanzania was partly contributed by the economy liberalization in 1980's and financial sector reforms in 1990's. Initially, all bank institutions were state owned under nationalization of all major organizations in the country. The financial sector reform allowed establishment of several private banks from 4 to 58 in 2017 [9]. The increase in number of banks resulted into competitive business environment which in turn resulted into the challenges of retaining the reputable employees [31], [37].

Sagaciously, the importance of employee retention has compelled many bank institutions to take curative initiatives
[54]. Specifically, the Tanzanian banks have adopted different employee retention strategies and initiatives [42]. Despite these strategies and initiatives, still there is a problem of retaining desirable employees. This may imply that the adopted retention strategies and initiatives might have inadequacy understanding or needs to be tailored to the Tanzanian context. Probably, the specific factors leading to bank employee retention are not addressed or ignored.

It is essential to address the employees' retention as it is highly link to organization performance. Kavitha et al. indicated that loosing key employees in an organization can lead to decline in the standard of service provision, service inconsistency and extra cost in new employee recruitment and training [26]. Mrope and Bangi argued that lack of employee retention strategies can result in poor organizational performance [40]. Similarly, Shahin admitted that poor employee retention can lead into operational problems, decreasing morale as well as increasing cost to the organization [59]. Given this situation, it is important to understand the factors that influence the Tanzanian banks employee retention. Notwithstanding that the empirical literature indicates many employee retention factors; this paper tests the influence of compensation on employee retention among banks in Tanzania.

Little has been done in empirical literature in addressing employee retention issues related to compensation in the Tanzania banks. Muhoho revealed that salaries and other benefits strongly influenced employee retention in Tanzanian other organizations [44]. Oyagi and Kembu focused in the learning institutions revealed that monetary incentives had significant influence on employee retention [49]. However, other studies have indicated some conflicting findings and conclusions. For instance, Msengeti and Obwogi noted a weak influence of remuneration on employee retention in Kenya [41]. In contrast, Khoshnevis and Gholipour argued that compensation had positive and significant relationship with employee retention in the Melli Bank of Iran [27]. Given the conflicting findings in the empirical literature and the challenges of retaining bank employees, it is essential to do a thorough study. Thus, this article aims at filling the gap by investigating the influence of compensation on employee retention in the banking institutions. 


\section{EMPLOYEE RETENTION AND COMPENSATION}

The concept of employee retention is defined by several scholars to fit their context of analysis. This article has adopted the definition by Gayathri et al. [15] who defined employee retention as a process in which employees are encouraged to stay with the organization for the maximum period of time or until the completion of the project. Kavitha et al. defined employee retention as deliberate efforts to retain quality individuals in the organization [26]. Despite that many scholars such as Regina and Rosalia contend that there is no single factor for employee retention, but this paper focused only in investigating the influence of compensation on employee retention [55]. According to Anis et al., compensation refers to cash and non-cash remuneration (such as salary and wages, benefits, bonuses and vacations) provided by the employer for the services rendered [6].

Herzberg two factor theory of 1966 provided a background for this study. The theory suggests that there are certain factors in the workplace that cause job satisfaction (and motivation) while others cause dissatisfaction. According to Herzberg, two factor theory, motivation of employees at workplace would occur only as a result of the use of motivators such as achievement, responsibility, the work itself, recognition, advancement and growth [17]. Whereas hygiene factors such as company policy and administration, interpersonal relations, salary, supervision, job security and working conditions, would not motivate or create satisfaction to employees but instead it would result in a neutral state.

The Herzberg two factor is a motivation theory and it was developed to study employee motivation. However, this paper considered it to be relevant in studying employee retention as it has been empirically evidenced [39], [64]. The scholars observed that when employees are motivated or satisfied at work they are likely to stay in their organizations. The applicability of this theory in studying employee retention has been observed and evidenced in several empirical studies such as [41], [62]. Adzei and Atinga linked motivation and retention of health workers in Ghana [1]. Chen et al. used Herzberg two factor theory to study employee retention and revealed a significant relationship between compensation and employee retention [10].

Rakhra did a study on employee retention at companies in India indicated that compensation contributed significantly on retention of employees [53]. Hong et al. studied employee retention in Malaysia revealed a significant relationship between compensation and employee retention [19]. Eberendu and Okere on studying motivation as a constituent to employees' retention, found that performance-based compensation was among core motivation factors that influenced employee retention [13]. Similarly, Kanwal and Majid on studying employee retention in the banking industry in Pakistan observed that low pay, absence of bonus and rewards schemes had significant impact on employee retention [24].

Patil and Sharma concluded that compensation is significantly influencing employee retention at the Plastic manufacturing companies in India [51]. Ahmada et al. who did a study at the banking industry of Pakistan revealed that attractive rewards are important strategies on retaining employees [5]. Sarmad et al. who conducted a study in
Pakistan and used multiple regression analysis, pointed out that compensation had significant impact on employee retention [58]. Similarly, Kossivi et al. indicated that compensation contribute significantly on employee retention [29]. In related perspective, Mamahit et al. on studying employee retention at a large hotel in Indonesia concluded that compensation had significant influence on employee retention [34]. Khoshnevis and Gholipour argued that compensation had positive and significant relationship with employee retention at Melli Bank in Iran [27].

Similarly, Mehrez and Bakri conducted a study in Qatar and used Structural Equation Modelling in data analysis indicated a positive and significant relationship between compensation and employee retention [38]. In the same line of argument, Nasir and Mahmood found a significant relationship between rewards and employee retention at various organizations in Pakistan [46]. Despite that the empirical studies [27], [58] evidenced the significant relationship between compensation and employee retention but some studies indicated contrary findings. For instance, Msengeti and Obwogi indicated insignificant influence of remuneration on employee retention [41].

In African context, Nnabuife et al. in studying rewards and employee retention in Nigeria observed a significant relationship between monetary rewards and employee retention [47]. Reddy and Govender did a research on retention of workers at a leading South African bank [54]. Using Chi-square test in data analysis, the study indicated that remuneration contributed significantly in influencing employees to stay at the bank. On the other hand, Mutiria et al. indicated that welfare benefits greatly influenced employee retention at Meru University in Kenya [45]. The attributes of welfare benefits that were revealed to have influence on retention of employees include pension scheme, retirement scheme and leave scheme. There is a need to increase the coverage by extending the study in other industries, that is, bank industry with a focus on investigating the influence of compensation on employee retention.

In Ugandan context, Kajungu and Mugisha carried a study on the role of remuneration in retention of health workforce in a rural district setting in Uganda [23]. Using correlation analysis, the study revealed a relationship between remuneration and employee retention. However, correlation analysis lacks ability to examine significance level, so the current study used binary logistic regression to overcome the weakness as logistic regression can examine the significant effect between compensation and employee retention.

In Tanzania, Muhoho pointed out that salaries and other benefits strongly influence employee retention and recommended regular review of the remunerations and good retirement plans [44]. Similarly, Oyagi and Kembu studied the public higher learning institutions in Dar es Salaam revealed a significant influence of monetary incentives on employee retention [49]. The cited empirical studies provide evidence on the existence of relationship between compensation and employee retention.

\section{CONCEPTUAL FRAMEWORK}

The article adopted a conceptual framework from the literature review where an independent variable 
'Compensation' (C) and a dependent variable 'Employee Retention' (ER) were constructed as illustrated in Fig. 1.

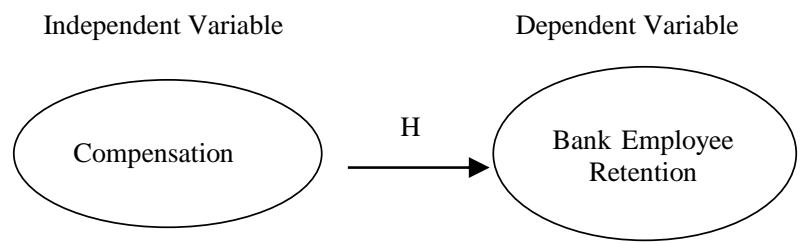

Fig.1. Conceptual framework. Source: Various literatures (2019)

\section{Methodology}

The quantitative method was used to gather suitable statistical data to test the hypothesis. The positivism philosophy was adopted in developing the hypothesis to explain the influence of compensation on employee retention at the banking institutions. Lancaster argued that positivism philosophy assumes that the study is independent, concentrates on facts by testing hypothesis and there are no human interests [32]. The survey strategy was employed to give statistical data for testing hypothesis. Explanatory research design helped to test the existence of causal relationships among variables and to validate a model to explain employee retention in aspects of compensation in the context of banking institutions.

The study area was Dar es Salaam region, the business capital of the Tanzania where most banks operates. Stratified sampling was used to ensure representativeness of banks basing on their categories. Eleven banks were selected purposely to ensure representativeness and simple random sampling was used to draw a sample of 370 employees. The sample size was allocated proportionally among the eleven selected banks depending on their number of employees.

The pilot study was conducted before the main survey to ensure the suitability of data collection instrument. Data analysis was done using both descriptive and inferential analysis. Binary logistic regression analysis was used to test the hypothesis and to develop a model that can explain the relationship between compensation and employee retention among banking institutions in Dar es Salaam. The IBM SPSS 23 software was employed to support the analysis in the study.

\section{STUDY FINDINGS}

\section{A. Descriptive data analysis}

The frequency and percentage were used in the descriptive data analysis in order to profile and gain an understanding of various respondents' characteristics.

\section{B. Gender of the respondents}

The findings on gender of the respondents indicated that female respondents were slightly higher than male respondents as among the 326 respondents contacted, $41.1 \%$ were male and $58.9 \%$ were female. This proportional of the percentage indicates representation of gender in the study as the data captured in Fig. 2.

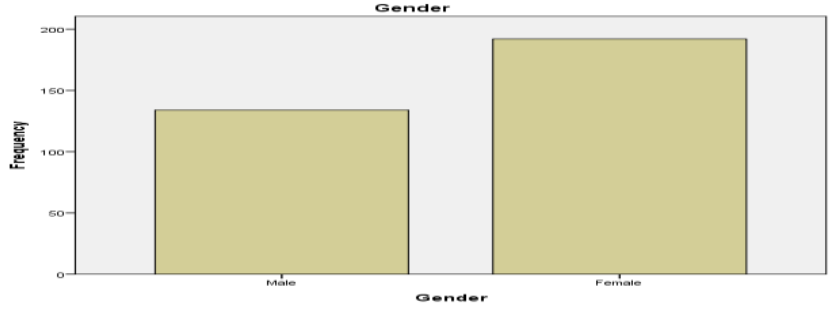

Fig.2. Gender representation.

\section{Age of the respondents}

The age groups were as follows; $30.7 \%$ were aged between 20-30 years, $48.5 \%$ were aged between 30 - 40 years, $14.7 \%$ were aged between 40 - 50 years and $6.1 \%$ were aged between 50 - 60 years as indicated in Fig. 3.

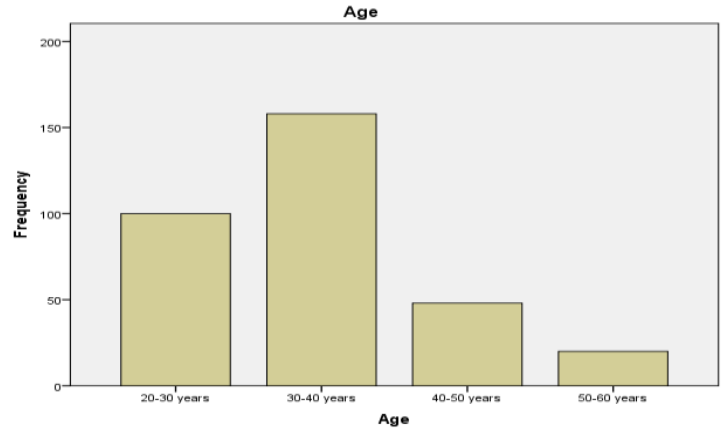

Fig. 3. Age frequencies.

D.

\section{E. The respondents level of education}

The findings on the level of education indicated that the majority $(66.6 \%)$ had first degree or its equivalent (Bachelor's degree), (27\%) had postgraduate degrees, (4.6\%) had qualification higher than secondary schools (Diploma) while a few $(1.8 \%)$ had secondary education qualifications. Majority of the respondents involved had good level of education as summarized in Fig. .4

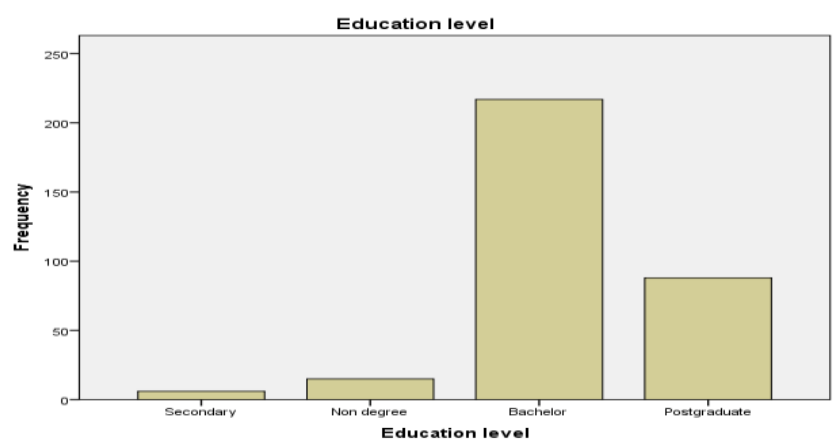

Fig. 4. Respondents education level.

\section{F. Marital status of the respondents}

The study revealed that $57.7 \%$ were married, $38 \%$ were single, $2.1 \%$ were widow and $2.1 \%$ were divorced/separated. Majority of respondents were married and single, however the proportional of the percentage indicated representation as shown in Fig. 5. 


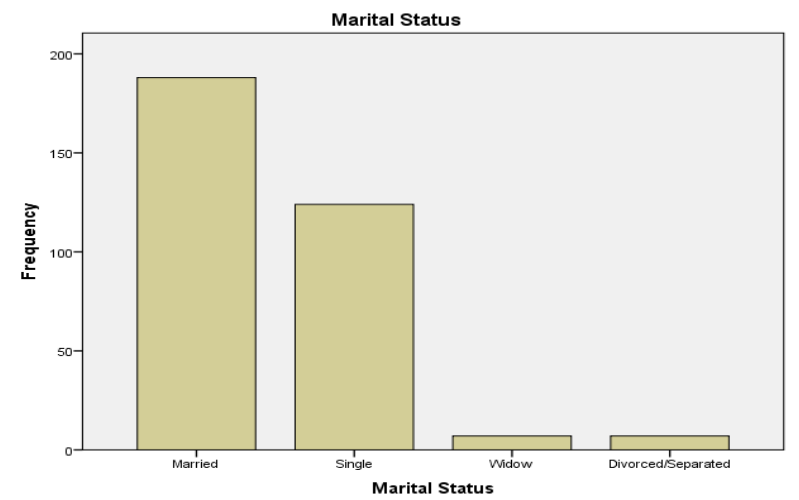

Fig. 5. Respondent's marital status.

\section{G. Management level of the respondents}

The findings indicated that majority of the banks staff $(60.4 \%)$ were non-management employees, (37.1\%) were mid-level management employees while a few $(2.5 \%)$ were top management employees. Each management level was involved in the study as it was considered that each tier may have different need that may influence a decision to stay [63] as summarized in Fig. 6.

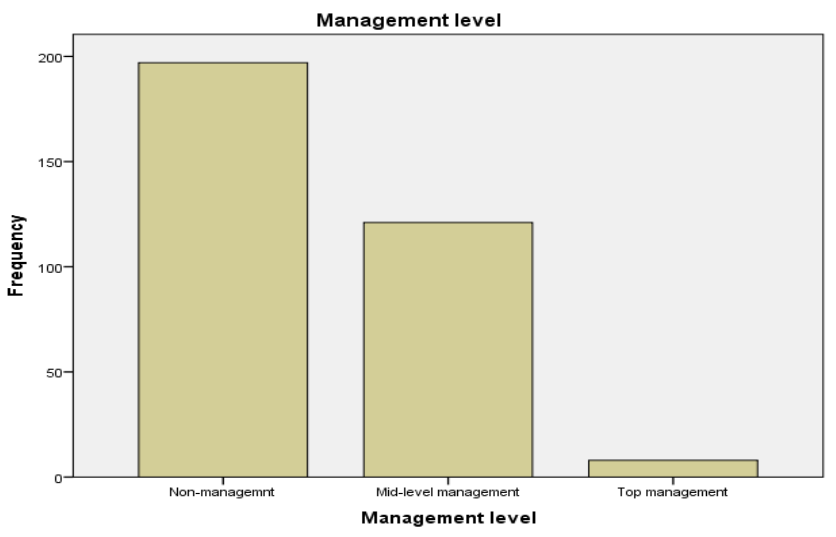

Fig. 6. The banks management levels.

\section{H. The banks respondents work experiences}

The study results revealed that out of 326 respondents, $5.2 \%$ had worked less than 1 year, $46.9 \%$ had worked from 1 to less than 5 years, $29.4 \%$ have worked from 5 to less than 10 years and $18.4 \%$ have worked above 10 years. The data covered each group category as the study considered that the number of years an employee has worked may have influence on their decision to stay as argued by (Agyeman and Ponniah, 2014). Fig. 7 shows frequencies for the banks employees working experiences.

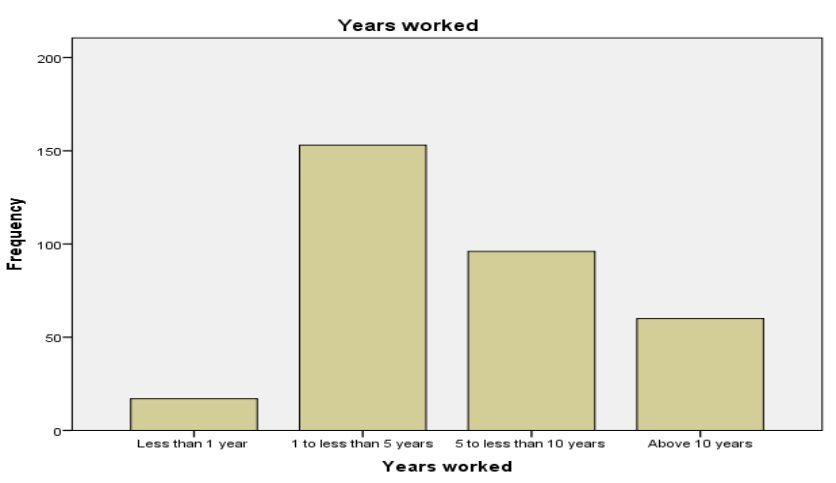

Fig. 7. Bank respondents work experiences.

\section{Validity and Reliability}

Validity and reliability issues were considered in testing the trustworthiness of the measurement instrument [21]. Content validity, construct validity and criterion validity were observed in ensuring validity [12]. A pilot study of survey instrument was done in order to ensure that the items in the questionnaire accurately reflect the theoretical domain of the latent construct it claims to measure. This involved few experts in human resource especially in compensation aspects and few respondents as a sample population to help the study to strengthen the data collection instrument.

To ensure construct validity, correct operational measures for the compensation (C) construct were identified. To ensure criterion validity, the data collection instrument was drawn and developed by considering strong validated literature and expert panels. Kimberlin and Winterstein argue that criterion validity provides evidence about how well scores on the new measure correlate with other measures of the same construct or very similar underlying constructs that theoretically should be related [28].

The paper also gave careful consideration on reliability by first ensuring that the data collection instrument was suitable to respondents, and second, assessing the internal consistency of the scale using Cronbach's Alpha. It was ensured that the language used in the questionnaire was clear to the respondents and hence the data collection instrument was suitable to them. A reliability analysis on the compensation scale comprising five items showed that the questionnaire attained an acceptable reliability with Alpha coefficient $(\alpha)$ equal to 0.861 as indicated in Table I. The obtained Alpha was within the acceptable range as it was between 0.7 and 0.9 as suggested by [61]. Streiner recommended a maximum value of Alpha coefficient $(\alpha)$ of 0.9 as when it is above that it can be too high and point to redundancy among the items [61].

TABLE I: RELIABILITY STATISTICS

\begin{tabular}{|c|c|}
\hline Cronbach's Alpha & $\begin{array}{c}\text { Cronbach's Alpha Based on } \\
\text { Standardized Items }\end{array}$ \\
\hline 0.861 & 0.862 \\
\hline
\end{tabular}

It was further checked if Alpha coefficient could increase by removing some items in the questionnaire. The study retained all items as any deletion of an item would have resulted in a decrease in the Alpha coefficient. The Cronbach's Alpha if item deleted column is shown in Table II.

TABLE II: RELIABILITY STATISTICS

\begin{tabular}{|c|c|c|c|c|c|}
\hline & $\begin{array}{c}\text { Scale Mean } \\
\text { if Item } \\
\text { Deleted }\end{array}$ & $\begin{array}{c}\text { Scale } \\
\text { Variance if } \\
\text { Item Deleted }\end{array}$ & $\begin{array}{c}\text { Corrected Item } \\
\text {-Total } \\
\text { Correlation }\end{array}$ & $\begin{array}{c}\text { Squared } \\
\text { Multiple } \\
\text { Correlation }\end{array}$ & $\begin{array}{c}\text { Cronbach's } \\
\text { Alpha if } \\
\text { Item Deleted }\end{array}$ \\
\hline C2 & 11.99 & 16.348 & 0.621 & 0.416 & 0.846 \\
\hline C3 & 11.68 & 15.578 & 0.708 & 0.513 & 0.824 \\
\hline C5 & 11.89 & 15.446 & 0.654 & 0.446 & 0.839 \\
\hline C6 & 11.92 & 15.707 & 0.746 & 0.576 & 0.816 \\
\hline C8 & 11.87 & 15.990 & 0.671 & 0.484 & 0.834 \\
\hline
\end{tabular}

Key Note: C2 = Fair salary, C3 = Incentives, C5 = Allowances, C6 = Meritpay, C8 = Pay increase.

\section{J. Hypothesis testing}

The objective of the paper was to test the hypothesis which state; Compensation has significant influence on employee retention at the banking institutions in Dar es Salaam. 
Findings using binary logistic regression are as presented in the following tables.

Table III pointed out a significant value (p) equal to 0.001 which is less than 0.05 . This implies that the predictor (compensation) makes a significant contribution in predicting employee retention. Hence, the hypothesis $\mathrm{H}$ is accepted. Further results of the study were also presented in Table IV.

TABLE III: VARIABLES IN THE EOUATION

\begin{tabular}{|c|c|c|c|c|c|c|c|}
\hline \multicolumn{2}{|l|}{} & B & S.E. & Wald & Df & Sig. & $\operatorname{Exp}(\mathrm{B})$ \\
\hline Step 0 & Constant & -0.360 & 0.113 & 10.209 & 1 & 0.001 & 0.698 \\
\hline
\end{tabular}

TABLE IV: VARIABLES IN THE EQUATION

\begin{tabular}{|c|c|c|c|c|c|c|c|c|c|}
\hline & & \multirow{2}{*}{$\mathrm{B}$} & \multirow{2}{*}{ S.E. } & \multirow{2}{*}{ Wald } & \multirow{2}{*}{ Df } & \multirow{2}{*}{ Sig. } & \multirow{2}{*}{$\operatorname{Exp}(B)$} & \multicolumn{2}{|c|}{ 95\% C.I.for EXP(B) } \\
\hline & & & & & & & & Lower & Upper \\
\hline \multirow{6}{*}{ Step $1^{\mathrm{a}}$} & $\mathrm{C} 2$ & -0.367 & 0.132 & 7.758 & 1 & 0.005 & 0.692 & 0.535 & 0.897 \\
\hline & C3 & -0.195 & 0.139 & 1.964 & 1 & 0.161 & 0.823 & 0.627 & 1.081 \\
\hline & $\mathrm{C} 5$ & -0.125 & 0.121 & 1.076 & 1 & 0.300 & 0.882 & 0.696 & 1.118 \\
\hline & C6 & -0.175 & 0.160 & 1.201 & 1 & 0.273 & 0.839 & 0.613 & 1.148 \\
\hline & $\mathrm{C} 8$ & -0.101 & 0.141 & 0.513 & 1 & 0.474 & 0.904 & 0.685 & 1.192 \\
\hline & Constant & 2.418 & 0.430 & 31.568 & 1 & 0.000 & 11.227 & & \\
\hline
\end{tabular}

a. Variable(s) entered on step 1: C2, C3, C5, C6, C8.

The results presented in Table IV indicate that out of five indicator variables only one indicator known as C2 (fair salary) was statistically significant. From these results you can see that $\mathrm{C} 2(\mathrm{p}=0.005)$ added significantly to the model/prediction, but C3 ( $\mathrm{p}=0.161), \mathrm{C} 5(\mathrm{p}=0.300)$, C6 $(p=0.273)$ and $C 8(p=0.474)$ did not add significantly to the model.

Thus, the hypothesis which state that compensation has significant influence on employee retention is confirmed. These results align with other findings [11] which indicated a significant influence of compensation on employee retention at the selected commercial banks in Nigeria. The hypothetical model developed from the findings is indicated in Fig. 8.

The insignificant attributes (indicators) of compensation were included in the derived model as these also can have influence on employee retention as some employees are very sensitive. This is due to the fact that employees are not the same as they have different sensitivity levels, satisfaction levels, altitudes, behaviours and perceptions as argued by [65]. Babyak suggest that non-significant values based on $\mathrm{p}$ value alone does not mean no effect and that insignificant values can be important in some situations for example in deciding which parameters to include or not to include in an intervention programme to a public health problem [8]. Similarly, Hirpara et al. argued that the presence of statistical significance does not necessarily mean clinically important when interpreting clinical research as the size of effect is the one that determines it [18].

Wald Chi-Squared Test for the insignificant attributes was also not zero as shown in Table IV, this indicated that each insignificant attribute had some contribution to the model despite that it is small [2], [3]. Hence, deleting insignificant indicator variables in the model would have resulted overfitting. Harrell Jr and Slaughter argued that removing indicators with little influence from the model results overfitting and hence an overfitted model [16]. Similarly, Babyak contended that overfitting yields overly optimistic model results and the findings from the overfitted model do not really exist in the population and hence can't be replicated [8].

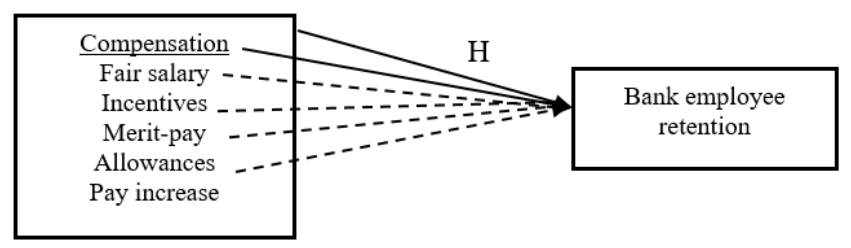

Fig. 8. Hypothetical Model for the Study.

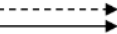
Insignifican
Significant

\section{FINDINGS DISCUSSION}

Contribution of compensation on employee retention at banking institutions have been confirmed in previous studies [50], [60]. So, employees at the banks in Dar es Salaam can be influenced by compensation. The study confirms that one hypothesis that compensation has significant influence on employee retention at the banking institutions in Dar es Salaam. Findings from binary logistic regression analysis indicated a significant $\mathrm{p}$-value of 0.001 which confirm that there is a significant relationship between compensation and employee retention. Prior studies [50], [56] have supported these results by reporting a significant contribution of compensation on employee retention.

Compensation was identified to be strongly associated to bank employee retention as it scored a p-value equal to 0.001 . Only one attribute, that is, fair salary was identified to explain employee retention, whereas other compensation attributes such as incentives, allowances, merit-pay and pay increase were insignificantly related to the bank employee retention. The results support the arguments made by [1] on Herzberg two factor theory that motivational factors such as salary supplements, benefits and allowances are significant predictors of employee retention in Ghana. Samuel and Chipunza revealed that an extrinsic variable of Herzberg, salary package has significant contribution on employee retention [57].

These findings corroborate with Osibanjo et al. who revealed that compensation have positive and significant influence on employee retention [48]. However, all the attributes of compensation used on their study namely salary, bonus, incentives, allowances and fringe benefits explain the relation between compensation and employee retention. But in this paper findings show that only one attribute of 
compensation (fair salary) contribute significantly towards employee retention.

Previous studies [19], [50] revealed a significant relationship between compensation and employee retention. Ejaz and Akbar indicated that compensation has a positive impact on employee retention at insurance companies in Pakistan [14]. Muindi and Odandi who did a study on factors that influence the retention of rural health workers in Siaya County in Kenya, found insignificant contribution of compensation on employee retention [43]. This contrary finding as compared to most previous studies may be due to poor application of compensation strategy in influencing employee retention as suggested by [33]. Therefore, good application of the strategy in retaining employees can be a good way of improving retention within the organization. Among others, one way of doing this can be through using compensation elements that are valued most by employees.

Most studies [7], [14] have shown a relationship between compensation and employee retention but compensation attributes used in different organizations in order to influence employee retention are not the same [48], [56]. Despite that compensation can improve employee retention in the banking institutions through providing fair salary as revealed in this paper, other compensation elements that were not included in the study might have influence on employee retention.

Fair salary in this paper represents a salary which is perceived by an employee to be commensurate to work or job responsibilities [64]. Empirical studies have explained that a salary that is fair to job responsibilities is a necessary compensation element that could be used by organizations in retaining employees [30], [60]. Kumar and Benitto who did a study on employee retention strategies using a case study in garment industries in India, revealed that salary was a major factor in retaining employees [30]. Waweru and Kagiri argued that when the salary paid to employees is not commensurate to the work, it doesn't make them feel fully appreciated for their work and effort and hence can't stay long [64]. The study also insisted that salary structures used should provide fairness to employees in relation to salaries. This paper relates fair salary to employee retention at the banks in Dar es Salaam.

Salary that is fair to job responsibilities was pointed out in this paper to have significant contribution in influencing employee retention as it had a significant p-value of 0.005 . These findings support the argument made by [25] on Herzberg two factor theory that there is a positive and significant relationship between salary and employee retention. Mathimaran and Kumar found salary to have positive and significant contribution on employee retention [36]. On the other hand, Ponnuru and Gupta concluded that salary has strong influence on retention of employees [52]. It can therefore imply that when the organization provides salary that is considered fair to the employees' job responsibilities it will have a significant influence in retaining those employees.

Salisu et al. found opposite results that salary is insignificantly influencing employee retention at Jigawa state in Nigeria [56]. This aligned with the argument made by Chiekezie et al. that there is a positive weak relationship between salary and employee retention [11]. Their study went further by concluding that in order for salary to have strong impact on retention of employees, the management of the organizations need to formulate, administer and implement good compensation policies. This indicates that there is a need of having good compensation policies that would come up with salaries that are perceived to be fair to employees thereby satisfying them and retain them in the organization.

These findings may imply that inability to retain employees in an organization can be contributed by salaries that are not perceived to be adequate compared to job responsibilities. This implication is aligned by Osibanjo et al. who advocated that organizations that have better compensation systems and policies in place put a very positive impact on their employees and hence become committed to the organization and remain [48]. Similarly, Salisu et al. concluded that it is crucial to have compensation package that is adequate and capable of retaining workers as it may come up with salaries that can satisfy and retain employees [56].

\section{CONCLUSION AND RECOMMENDATION}

The hypothesis on the influence of compensation on employee retention in the banking institutions in Dar es Salaam was tested and the model that can be used to explain employee retention specifically on compensation facets was developed. Grounded on employee retention literature, the study borrowed a factor from Herzberg dual factor theory to study employee retention in the banking institutions. This paper confirms that compensation has significant influence on employee retention. This result can help bank managers who are looking forward to retain employees especially on compensation aspects. The paper reveal further that fair salary is the most important attribute due to its significant contribution on employee retention. The bank management can consider this fact in developing and implementing compensation policies. Additional research on the contribution of compensation on employee retention can be conducted in other regions. The use of other data analysis techniques such as multiple regression and structural equation modeling can also be applied to study other parameters of employee retention.

\section{REFERENCES}

[1] Adzei, F.A. and Atinga R.A. (2012). "Motivation and retention of health workers in Ghana's district hospitals: Addressing the critical issues". Journal of health organization and management. 26(4): 467 - 485.

[2] Agresti, A. (1990). Categorical Data Analysis. John Wiley and Sons. New York.

[3] Agresti, A. (2013). Categorical Data Analysis (3rd Ed). John Wiley \& Sons Inc. Hoboken.

[4] Agyeman, C.M. and Ponniah, V.M. (2014). Employee Demographic characteristics and Their Effects on Turnover and Retention in MSMEs. International Journal of Recent Advances in Organizational Behaviour and Decision Sciences. 1(1): 12 - 29.

[5] Ahmada, N., Tariqb, M.S. and Hussain, A. (2015). Human resource practices and employee retention, evidences from banking sector of Pakistan. Journal of Business and Management Research. 7:186 188.

[6] Anis, A., Rehman, K., Rehman, I., Khan, M.A. and Humayoun, A.A. (2011). Impact of organizational commitment on job satisfaction and employee retention in pharmaceutical industry. African Journal of Business Management. 5(17): 7316 - 7324.

[7] Anter, C. and Lapian, S.L.H.V.J. (2016). Analyzing the Effect of Employee Compensation on Employee Intention to Stay (Study in Bank SulutGo Head Office). Journal EMBA. 4(2): 39 - 45.

[8] Babyak, M.A. (2004). What you see may not be what you get: a brief, nontechnical introduction to overfitting in regression-type models. Psychosomatic Medicine. 66: 411- 421. 
[9] BoT (2017). Directorate of banking supervision Annual Report.Government Printer, Dar es Salaam, Tanzania. [https://www.bot-

tz.org/BankingSupervision/BankingSupervision.asp] site visited on 20/01/2019.

[10] Chen, Y.S., Rasdi, R.M., Ismail, M. and Asmuni, A. (2017). Predictors of Intention to Stay and Moderating Role of Gender among Executives in the Malaysian Manufacturing Organizations. International Journal of Academic Research in Business and Social Sciences. 7(special issue). 4th International Conference on Educational Research and Practice,Malaysia. [http://hrmars.com/hrmars_papers/Predictors_of_Intention_to_Sta y_and_Moderating_Role_of_Gender_among_Executives_in_the_ Malaysian_Manufacturing_Organizations.pdf] site visited on $12 / 05 / 2017$.

[11] Chiekezie, O.M., Emejulu, G. and Nwanneka, A. (2017). Compensation management and employee retention of selected commercial banks in Anambra state, Nigeria. Archives of Business Research. 5(3): 115 - 127

[12] Drost, E.A. (2011). Validity and Reliability in Social Science Research. Education Research and Perspectives. 38(1): 105 - 124.

[13] Eberendu, A.C. and Okere, R.K. (2015). An empirical review of Motivation as a Constituent to Employees' Retention. International Journal of Engineering and Science. 5(2): 6-15.

[14] Ejaz, S. and Akbar, W. (2015). An Effectiveness of Human Resource Management Practices on Employee Retention Findings from Insurance Companies of Karachi. European Journal of Business and Management. 7(7): 27 - 33.

[15] Gayathri, R., Sivaraman, G. and Kamalambal, R. (2012).Employee retention strategies in BPO's- An empirical investigation. Interdisciplinary Journal of Contemporary Research in Business. 3(12): 572 - 583.

[16] Harrell Jr, F.E and Slaughter, J.C. (2008). Introduction to Biostatistics for Biomedical Research. http://biostat.mc.vanderbilt.edu/wiki/pub/Main/ClinStat/ci2.biostat 1.pdf] site visited on 22/09/2019.

[17] Herzberg, F. (1966). Work and the nature of man. Thomas Y. Crowell Company. New York.

[18] Hirpara, N., Jain, S., Gupta, A. and Dubey, S. (2015). Interpreting research findings with confidence interval. Journal of Orthodontics \& Endodontics. 1(8): $1-4$.

[19] Hong, E.N., Hao, L.Z., Kumar, R., Ramendran, C. and Kadiresan, V. (2012). An effectiveness of human resource management practices on employee retention in institute of higher learning: - a regression analysis. International Journal of Business Research and Management. 3(2): 60 - 79.

[20] Ibidunni, S., Osibanjo, O., Adeniji, A., Salau, O.P. and Falola, H. (2016). Talent Retention and Organizational Performance: A Competitive Positioning in Nigerian Banking Sector. Social and Management Sciences. 24(1): $1-13$.

[21] Ihantola, E. and Kihn, L. (2011). Threats to Validity and Reliability in Mixed Methods Accounting Research. Qualitative Research in Accounting and Management. 8(1): 39 - 58.

[22] Johari, J., Yean, T.F., Adnan, Z., Yahya, K.K. And Ahmad, M.N (2012). Promoting Employee Intention to Stay: Do Human Resource Management Practices Matter? International Journal of Economics and Management. 6(2): 396 - 416.

[23] Kajungu, T.M. and Mugisha, J.F. (2015). Role of remuneration in retention of health workforce in a rural district setting in Uganda. International Journal of Public Health Research. 3(1): 10 - 16.

[24] Kanwal, A. and Majid, M. (2013). Retention Management in Banking System: An Evidence from Multan, Punjab Pakistan. Interdisciplinary Journal of Contemporary Research in Business. 5(1): $795-804$

[25] Kassa, T. (2015). Employee Motivation and its Effect on Employee Retention in Ambo Mineral Water Factory. International Journal of Advance Research in Computer Science and Management Studies. 3(3): 10 - 21.

[26] Kavitha, S.R., Geetha, S.R.and Arunachalam, V. (2011). An empirical study on employee retention strategies in a biscuit manufacturing company in India. Interdisciplinary Journal of Contemporary Research in Business. 3(4): 762 - 772.

[27] Khoshnevis, M. and Gholipour, A. (2017). Exploring the Relationship between Employer Brand and Employees' Retention. International Journal of Scientific and Engineering Research. 8(10): $141-151$

[28] Kimberlin, C.L. and Winterstein, A.G. (2008). Validity and reliability of measurement instruments used in research. American Journal of Health-System Pharmacists.65: 2276 - 2284.

[29] Kossivi, B., Xu, M. and Kalgora, B. (2016). Study on Determining Factors of Employee Retention. Open Journal of Social Sciences. 4: $261-268$.

DOI: http://dx.doi.org/10.24018/ejbmr.2020.5.4.223
[30] Kumar, J.S. and Benitto, J.J. (2015). Employee Retention Strategies -A Case Study on Garment Industries in Tirupur. Asia Pacific Journal of Research. 1(33): 91 - 96.

[31] Kweka, N.A and Sedoyeka, E. (2014). Labor Turnover in Tanzania - Telecom vs Banking Sectors. International Journal of Computing and ICT Research. 8(2): $65-82$

[32] Lancaster, G. (2005). Research Methods: A Concise Introduction to Research in Managements and Business Consultancy. ButterworthHeinemann. London.

[33] Mabaso, C. and Moloi, K.C. (2016). The Influence of Compensation on Talent Retention at a TVET College [https://papers.ssrn.com/sol3/papers.cfm?abstract_id=2851760] site visited on $26 / 12 / 2018$.

[34] Mamahit, N.I., Worang, F.G. and Rumokoy, F.S. (2019). Factor Analysis on Employee Retention at Ibis Hotel Manado. Journal EMBA. 7(1): $121-130$

[35] Manogharan, M.W., Thivaharan, T. and Rahman, R.A. (2018) Academic staff retention in private higher education institute - case study of private colleges in Kuala Lumpur. International Journal of Higher Education. 7(3): 52 - 78.

[36] Mathimaran, B. and Kumar, A.A. (2017). Employee Retention Strategies - An Empirical Research. Global Journal of Management and Business Research: E Marketing. 17(1): 17 - 22

[37] Mboya, W.J. (2012). Model for Determinants of Labour Mobility in the Banking Industry of Tanzania. The African Journal of Finance and Management. 21(2) [http://journal.ifm.ac.tz/index.php/AJFM/article/view/51] site visited 22/06/2016.

[38] Mehrez, A. and Bakri, A. (2019). The impact of human resource practices on job satisfaction and intention to stay in emerging economies: Model development and empirical investigation among high caliber governmental employees in Qatar. Management Science Letters. 9 (2019): 425 - 442.

[39] Motlou, R.G. and Karodia, A.M. (2016). An evaluation of the impact of job satisfaction on employee retention at Lonmin Rowland Shaft North West province. Kuwait Chapter of Arabian Journal of Business and Management Review. 5(10): 15 - 49.

[40] Mrope, G. and Bangi, Y.I. (2014). Examining the Influence of Management Practice and Attitudes on Employee Turnover: A Case of Kibaha District Council. The International Journal of Business and Management. 2(9): $11-18$

[41] Msengeti, D.M. and Obwogi, J. (2015). Effects of Pay and Work Environment on Employee Retention: A Study of Hotel Industry in Mombasa County. International Journal of Scientific and Research Publications. 5(4): 2250 - 3153

[42] Msisiri, P. R. and Juma, D. (2017). Relationship between nonfinancial rewards and retention of employees in banking industry: Case of Commercial Rural Development Bank-Arusha Tanzania International Journal of Economics and Finance. 5(2): 1-38.

[43] Muindi, F. and Odandi, C.A. (2016). Factors that influence the Retention of Rural Health Workers in Siaya County, Kenya. DBA Africa Management Review. 6(3): 27 - 41.

[44] Muhoho, J.M.E. (2014). Assessment of factors influencing employee retention in Tanzania's work organizations. International journal of innovation and applied studies. 9(2): 687 - 697.

[45] Mutiria, J.K., Rukangu, S. and Kubaison, K. (2015). Factors Influencing Employee Retention at Meru University of Science and Technology. IOSR Journal of Business and Management. 17(11) $75-82$.

[46] Nasir, S.Z. and Mahmood, N. (2016). Determinants of Employee Retention: An Evidence from Pakistan. International Journal of Academic Research in Business and Social Sciences. 6(9): $182-$ 194.

[47] Nnabuife, E.K., Chiekezie, O.M. and Elom, M.E. (2017). Rewards and Employee Retention in Ebonyi State Public Corporations: Focus on Ebonyi State Broadcasting Corporation and Ebonyi State Water Corporation. Journal of Business and Management. 19(12) $56-63$.

[48] Osibanjo, O.A., Adeniji, A.A., Falola, H.O. and Heirsmac, P.T (2014). Compensation packages: a strategic tool for employees performance and retention. Leonardo Journal of Sciences. 13(25): $65-84$.

[49] Oyagi, N.B. and Kembu, S.A. (2014). To assess the relationship between motivation and retention of academic staff in selected public higher institutions of learning in Dar es-Salaam. International journal of advancement in engineering technology, management and applied science. 1(4):54 - 61.

[50] Palwasha, B., Faizuniah, P., Johanim, J. and Ashfaq, A. (2017). The Impact of Compensation and Promotional Opportunities on Employee Retention in Academic Institutions: The Moderating Role of Work Environment. International Journal of Economic Perspectives. 11(1): $378-391$. 
[51] Patil, Y.V. and Sharma, D.S. (2014). An Analytical Study of Role of Compensation \& Exit Interview on Employee Retention in Plastic Manufacturing Industry in Jalgaon District. DMIETR International Journal on Human Resource Management.1: 6 -10.

[52] Ponnuru, K.R. and Gupta, R. (2018). Employee Retention: Important factors to be considered by Human Resource Professionals while creating retention. [https://www.igiglobal.com/chapter/employee-retention/200002] site visited on 12/01/219.

[53] Rakhra, H.K. (2018). Study on factors influencing employee retention in companies. International Journal of Public Sector Performance Management. 4(1): 57 - 79.

[54] Reddy, K. and Govender, K.K. (2014). Retaining knowledge workers: a case study of a leading South African bank. Mediterranean journal of social sciences. 5(23): 2768 - 2776.

[55] Regina, C. Dy. and Rosalia, T.C. (2015). A Strategic Employee Retention Model Based on Employee Perception. European Journal of Business Management. 2 (5), 25-35.

[56] Salisu, J.P., Chinyio, E. and Suresh, S. (2016). The Impact of Compensation on Public Construction Workers' Retention in Jigawa State of Nigeria. International Journal of Engineering Sciences and Management. 6(2): 17 - 30.

[57] Samuel, M.O. and Chipunza, C. (2009). Employee retention and turnover: Using motivational variables as a panacea. African Journal of Business Management. 3(8): 410 - 415.

[58] Sarmad, M., Ajmal, M.M., Shamim, M., Saleh, M. and Malik, A (2016). Motivation and Compensation as Predictors of Employees' Retention: Evidence from Public Sector Oil and Gas Selling Organizations. Journal of Behavioural Sciences. 26(2): 175 - 188.

[59] Shahin, N. (2017). A Study of Employee Retention in the Pharmaceuticals Sector in Ranchi City. International Journal of Engineering Technology Science and Research. 4(9): 292 - 301.

[60] Silva, M.R.A., Carvalho, J.C.A. and Dias, A.L. (2019) Determinants of Employee Retention: A Study of Reality in Brazil [https://www.igi-global.com/chapter/determinants-of-employeeretention/221181] site visited on 20/01/2019.

[61] Streiner, D.L. (2003). Statistical Developments and Applications, Starting at the Beginning: An Introduction to Coefficient Alpha and Internal Consistency. Journal of Personality Assessment. 80(1): 99 $-103$.

[62] Thirupathy, A. and Dhayalan, C. (2016). Employee retention and turnover using motivational variables at India. International Journal of Research. 4(8): 1 - 9 .

[63] Uitzinger, D., Chrysler-Fox, P. and Thomas, A. (2016). Retention Strategies for Top and Middle-level Managers. Proceedings of the 28th Annual Conference of the Southern African Institute of Management Scientists, Johannesburg, South Africa. September 2016.

[https://www.researchgate.net/publication/307811720_Retention_s trategies for top-and middle-level_managers] site visited on 20/01/2019.

[64] Waweru, S.W. and Kagiri, A. (2018). Effect of Human Resource Management Strategies on Employee Retention: A Survey of Agriculture sector Ngo's based in Nairobi, Kenya. The Strategic Journal of Business \& Change Management. 5(2): 2340 - 2360.

[65] Zareen, M., Razzaq, K. and Ramzan, M. (2013). Impact of employee retention on performance: the moderating role of employee psychological perception towards retention plan. Interdisciplinary journal of contemporary research in business. 4(10): 822 - 830. 